This item was submitted to Loughborough's Research Repository by the author.

Items in Figshare are protected by copyright, with all rights reserved, unless otherwise indicated.

\title{
Media events and missionary periodicals: the case of the Boxer War, 1900- 1901
}

PLEASE CITE THE PUBLISHED VERSION

http://dx.doi.org/10.1017/S0009640713000085

\section{PUBLISHER}

Cambridge University Press @ American Society of Church History

VERSION

VoR (Version of Record)

\section{PUBLISHER STATEMENT}

This work is made available according to the conditions of the Creative Commons Attribution-NonCommercialNoDerivatives 4.0 International (CC BY-NC-ND 4.0) licence. Full details of this licence are available at: https://creativecommons.org/licenses/by-nc-nd/4.0/

\section{LICENCE}

CC BY-NC-ND 4.0

\section{REPOSITORY RECORD}

Klein, Thoralf. 2019. "Media Events and Missionary Periodicals: The Case of the Boxer War, 1900-1901". figshare. https://hdl.handle.net/2134/15757. 


\section{Church History}

http://journals.cambridge.org/CHH

Additional services for Church History:

Email alerts: Click here

Subscriptions: Click here

Commercial reprints: $\underline{\text { Click here }}$

Terms of use : $\underline{\text { Click here }}$

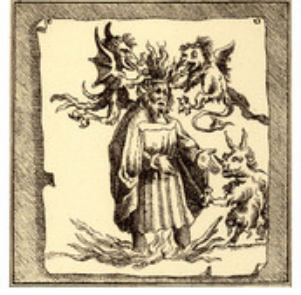

\section{Media Events and Missionary Periodicals: The Case of the Boxer War, 1900-1901}

\section{Thoralf Klein}

Church History / Volume 82 / Issue 02 / June 2013, pp 399 - 404

DOI: 10.1017/S0009640713000085, Published online: 20 May 2013

Link to this article: http://journals.cambridge.org/abstract_S0009640713000085

How to cite this article:

Thoralf Klein (2013). Media Events and Missionary Periodicals: The Case of the Boxer War, 1900-1901. Church History, 82, pp 399-404 doi:10.1017/ S0009640713000085

Request Permissions : $\underline{\text { Click here }}$ 


\title{
Media Events and Missionary Periodicals: The Case of the Boxer War, 1900-1901
}

\author{
THORALF KLEIN
}

$\mathrm{M}$ ISSIONARY periodicals, like their secular counterparts (newspapers and magazines), had the potential to create and sustain media eventsthose rare and precious times when news coverage breaks out of the confines of its daily routines, allowing contemporaneous themes to surface and occupy center stage. ${ }^{116}$ However, mission publications had their specific ways of presenting these issues, which are cast most sharply into relief when the underlying occurrences affected both missions and society at large. It is at those junctures that mission publications became more receptive towards broader political, social, and cultural trends; conversely, society took greater notice of missionary activities than usual during these times.

A case that illuminates this perfectly is the Boxer movement, which swept Northern China in the years between 1898 and 1901, triggering a crisis of imperialism and Christian missions in China. As this crisis of global proportions unfolded, the world held its breath. Particularly spectacular was the siege of about 1,000 "Western" nationals and 3,000 Chinese Christians, defended by 450 marines, in the Legations Quarter of Beijing and the foreign concessions in the port city of Tianjin in the summer of 1900; their relief by an international military force; the subsequent punitive expeditions against "Boxer villages"; and, the peace negotiations between China and the imperialist powers which led to the concluding of the Boxer Protocol of September 1901. At the same time, the ordeal of Protestant and Catholic missionaries was also taken note of: not a few of them were held up in Beijing and Tianjin during the siege; around 250 lost their lives in North China; many others just escaped their pursuers. Less reported was the perishing of tens of thousands of Chinese Christians as well as their role at the two sieges. I will use this spectacular case in order to throw some light on how a media event was delivered to mission circles.

Research on media events has focused mostly on their performative aspects as well as on the ways "real-life" occurrences are represented and in fact

\footnotetext{
${ }^{116}$ See: Friedrich Lenger, "Einleitung: Medienereignisse der Moderne," in Medienereignisse der Moderne, eds. Friedrich Lenger and Ansgar Nünning (Darmstadt: Wissenschaftliche Buchgesellschaft, 2008), 8.
}

Thoralf Klein is Senior Lecturer in Modern History at Loughborough University, U.K. 
construed in and by the media. ${ }^{117}$ What has yet to be appreciated is how media events are in fact serialized processes evolving over time. ${ }^{118}$ Media events are not isolated occurrences; even if they are sparked by individual incidents, coverage of the incidents must relate their effects and delve into their causes. For this reason, it is not live broadcasting alone that is able to construe media events as open-ended and unfolding right under the noses of an enthralled public. Already in the newspaper age, telegraphy enabled the global media network to keep abreast of developments world-wide, allowing for an open structure of the media event that took place against the backdrop of what Reinhart Koselleck has called an horizon of expectation. ${ }^{119}$

Media events are thus influenced by a number of factors: the ideological and institutional background of publication outlets, the available technology, the discursive frameworks, but also the development of the "real" occurrences. In what follows, I will examine this interplay on the basis of a sample of six missionary periodicals: three in English (The Mission Field, The Missionary Herald, and The Chinese Recorder and Missionary Journal); and three in German (China-Bote, Evangelisches Missions-Magazin and Die evangelischen Missionen). In addition to the different languages, these also differed as to national affiliations, denominational standpoints, and target audiences. Yet, as will be seen below, they shared a common discursive framework.

\section{Time, Technology, and Sources of Information}

In terms of creating a media event, one distinction that mattered was whether the periodical was a society or supra-denominational periodical. The Mission Field, Missionary Herald, and China-Bote were all published by a particular mission society and following its activities. Two of these societies were active in North China and hence were affected by the Boxer movement, while the China-Bote was connected to that region through its affiliation

\footnotetext{
${ }^{117}$ Daniel Dayan and Elihu Katz, Media Events: The Live Broadcasting of History (Cambridge, Mass.: Harvard University Press, 1992); Andreas Hepp and Nick Couldry, "Introduction: Media Events in Globalized Media Cultures," in Media Events in a Global Age, eds. Nick Couldry, Andreas Hepp, and Friedrich Krotz (London: Routledge, 2009), 1-20; Frank Bösch, "Ereignisse, Performanz und Medien in historischer Perspektive," in Medialisierte Ereignisse. Performanz, Inszenierung und Medien seit dem 18. Jahrhundert, eds. Frank Bösch and Patrick Schmidt (Frankfurt am Main: Campus, 2010), 7-29.

${ }^{118}$ Ruth Mayer, "The Greatest Novelty of the Age': Fu-Manchu, Chinatown, and the Global City," in Chinatowns in a Transnational World. Myths and Realities of an Urban Phenomenon, eds. Vanessa Künnemann and Ruth Mayer (New York: Routledge, 2011), 116.

${ }^{119}$ Reinhart Koselleck, "'Space of Experience' and 'Horizon of Expectation': Two Historical Categories," in Futures Past: On the Semantics of Historical Time, trans. Keith Tribe (New York: Columbia University Press, 2004), 255-275.
} 
with the China Inland Mission, a society that suffered particularly heavily during the Boxer crisis. ${ }^{120}$ Another two (Die evangelischen Missionen and Evangelisches Missions-Magazin) synthesised material from multiple missionary societies. The Chinese Recorder was unique in that it served as a forum of exchange for all missionaries in China. This meant that although it was not tied to a particular society, it had direct ties to missionaries on the ground.

The intimacy of connections with missionary work in North China determined the level of attention devoted to the Boxer disturbances in 1900. It is significant that those publications having a global outlook devoted far less attention - if the space devoted to the matter is any indication - to news from North China. ${ }^{121}$ For the others, which had a much greater stake in the outcome of the war, there was still the problem of time lag. Like many periodicals then and now, missionary periodicals usually appeared monthly. In an age when the telegraph had revolutionized news reporting, allowing information to be circulated globally with the speed of light, ${ }^{122}$ this made them appear rather sluggish. As letters took two to three months from the time they were written until their publication, missionary periodicals lagged behind developments in China and sometimes made the readers explicitly aware of this. ${ }^{123}$ Those periodicals that contained special sections digesting the latest incoming information had an edge over others, and they at least managed to create the same sense of anxiety that permeated the reporting in the secular press.

However, an altogether different understanding of news value and authenticity drove missionary periodicals. In the secular press, telegraphy was regarded as a medium that guaranteed the authenticity of the information transmitted. As telegraphic communication with the "Westerners" in Beijing was disrupted early on, the media resorted to speculations, albeit often with some qualifications - a process that culminated in the false rumor that all foreigners in Beijing had been slain by Boxers and Chinese Imperial troops. ${ }^{124}$ Missionary periodicals, on the other

\footnotetext{
${ }^{120}$ Alvyn J. Austin, China's Millions. The China Inland Mission and Late Qing Society, 1832 1905 (Grand Rapids, Mich.: Eerdmans, 2009), 395-415.

${ }^{121}$ Die evangelischen Missionen only published two articles on the situation in North China in 1900 (as opposed to five in 1901), the Evangelisches Missions-Magazin five rather lengthy articles (as opposed to nine in 1901). The Chinese Recorder does not seem to have noticed the impending crisis until its June edition of 1900.

${ }^{122}$ See: Roland Wenzlhuemer, "The Dematerialization of Telecommunication: Communication Centres and Peripheries in Europe and the World, 1850-1920," Journal of Global History 2 (2007): 345-372.

123"'Our Missionaries in China," Missionary Herald 96 (1900), 270; "Wie's jetzt steht," ChinaBote 9 (1900), 6.

${ }^{124}$ Paul A. Cohen, History in Three Keys: The Boxers as Event, Experience and Myth (New York: Columbia University Press, 1997), 161.
} 
hand, particularly those published by mission societies, valued personal letters from individual missionaries higher than telegraphic information. ${ }^{125}$ This is hardly surprising, given that detailed correspondence with missionaries was crucial to mission administration, and communication of such correspondence to supporting circles was pivotal to raising funds and support for the missionaries. Sparse telegrams would not have achieved the desired effect. For this reason, missionary periodicals were less susceptible to the "daily rumors" 126 transmitted by the secular press.

On the other hand, missionary periodicals participated in the sharing of knowledge that constituted the other important source of foreign news. Those with a global perspective were particularly dependent on information from other missionary periodicals, having no informants on the spot. Occasionally, material from the secular press was also incorporated, mostly background information on the general situation or important political actors. ${ }^{127}$ In so doing, they not only attested to the historical significance of the Boxer War, they also showed themselves to be part of the self-referential global media system that had emerged in the nineteenth century.

\section{Discourses And Horizons of Expectation}

All media events are endowed with significance by building on discourses that draw media, their producers, and their users together. In an open-ended situation laden with tension, relying on pre-existing modes of producing meaning may bring about relief by opening up an horizon of expectation promising (perhaps even guaranteeing) a certain outcome, be it positive or negative. By the same token, techniques of "re-mediation"128 portray what is unfolding at the moment as part of a larger chain of events, depriving the present occurrence of its singularity while at the same time endowing it with meaning. Coverage of the Boxer War by missionary periodicals is no exception to this. An extremely illustrative aspect is the role of the discourse on martyrdom. In both secular and missionary periodicals, the murder of the Society for the Propagation of the Gospel (SPG) missionary, Sidney Brooks, on New Year's Eve 1899 became the incident that marked the beginning of

\footnotetext{
125“"Our Missionaries in China," Missionary Herald 96 (1900), 270. Telegrams could be important in providing first news of rescue or death. See, "Telegramme," China-Bote 9 (1900), $9,23$.

126“"The Outbreak in China," Missionary Herald 96 (1900), 308.

${ }^{127}$ Examples include, "Die Belagerung von Peking," Evangelisches Missions-Magazin 44 (1900), 497-519; "Miscellany," Missionary Herald 96 (1900), 369.

${ }^{128}$ Astrid Erll, "Re-mediating '1857/58' in Fiction: Kim (1901) and Shunkur (1885)," Muse India (April 2006), http://www.museindia.com/viewarticle.asp?myr=2006\&issid=7\&id=309, accessed July 10, 2012.
} 
the Boxer crisis. Whereas the secular press took some time to begin making sense of the situation, missionary periodicals could rely on a handy interpretation: as early as May 1900, the SPG published an article on his martyrdom, which did not hint at an escalating crisis. ${ }^{129}$ One reason for this apparent lack of excitement was that from a mission perspective, martyrdom was by no means unusual compared to other incidents in China reported in missionary periodicals over the previous decades. ${ }^{130}$ Moreover, especially in an Anglo-Saxon context, there existed a centuries-old discourse on martyrdom. ${ }^{131}$ Indeed, as early as February 1900, the Mission Herald had stated what was to become a kind of leitmotif: "Now, as always, the blood of the martyrs is the seed of the church."

As the Boxer crisis went from bad to worse, martyrdom remained a focal point for the missionary periodicals. As a discursive figure, it connected the loss of missionary and Chinese Christian lives in China to the death toll of the church in the past and to salvation history. It also justified the continuation of the mission field, so that those who had perished would not have died in vain. ${ }^{133}$ The discourse on martyrdom thus also contained a script for the future of Christian missions in China.

\section{SHIFTS AND RUPTURES}

Irrespective of whether or not media events are connected to "real-life" occurrences or are produced exclusively within the media system, ${ }^{134}$ they are characterized by a dynamic fluidity that may lead to dramatic shifts of interpretation. As the producers of information can never fully control the course the event is taking, the "visible" and the "articulable" may take on new forms which may alter the ways in which meaning is construed. The parameters of what the media event was about in the first place - in other words, the horizons of expectation - are thus fundamentally altered. Again,

\footnotetext{
${ }^{129}$ H. Mathews, "Sidney Brooks' Martyrdom,” The Mission Field 45 (1900): 167-170.

130،Das Blut eines Märtyrers trägt Frucht," China-Bote 8 (1900), 87.

${ }^{131}$ Roger R. Thompson, "Reporting the Taiyuan Massacre. Culture and Politics in the China War of 1900," in The Boxers, China, and the World, eds. Robert Bickers and R. G. Tiedemann (Lanham, Md.: Rowman \& Littlefield, 2007), 66-67.

132،"Sunshine after clouds," in Missionary Herald 96 (1900), 45. See also, “An den Gräbern chinesischer Märtyrer," Evangelisches Missions-Magazin 45 (1901), 568.

${ }^{133}$ Judson Smith, "China, the Situation and the Outlook," in Missionary Herald 96 (1900), $462-$ 463. For the context, see also Albert Wu, "Catholic and Protestant Individuals in NineteenthCentury German Missionary Periodicals," Church History 82 (2013), 394-398.

${ }^{134}$ Kathrin Fahlenbrach, "Körper-Revolten und mediale Körperinszenierungen: Die Proteste um '68 als Medienereignis," in Medialisierte Ereignisse. Performanz, Inszenierung und Medien seit dem 18. Jahrhundert, eds. Frank Bösch and Patrick Schmidt (Frankfurt am Main: Campus, 2010), 229-231.
} 
missionary periodicals are no exception. The most striking example, however, resulted from a shift within the secular media. After the foreign settlements in Tianjin and Beijing had been relieved by an international expeditionary force in mid-July and mid-August 1900, the secular press began to change its attitude toward developments in China. Coverage of the "Western" intervention became more critical. It not only targeted the atrocities committed by the intervention troops, but also reported on cases where missionaries had extracted compensation-sometimes forcibly-from the local population. Moreover, some quarters argued that missionaries were responsible for the Boxer disturbances in the first place, since their presence had fuelled the tensions between the Christian minority and the non-Christian majority that had given rise to the Boxer movement.

Most of the ensuing debate took place in secular journals and magazines, such as the famous exchange between Mark Twain - one of the most outspoken critics of Christian missions and imperialism - and representatives of mission societies. ${ }^{135}$ Missionary periodicals felt that they had to respond to the charges and tried to immunize their readership against them, ${ }^{136}$ demonstrating my point that pressure from outside changed the character of the media event that was the Boxer War in missionary periodicals.

\section{CONCLUSION}

That missionary periodicals shaped the Boxer War as a media event in the same way as the secular press is not particularly surprising. Both relied on the same technologies and both appeared regularly, giving the coverage of developments in China a serial character. Missionary periodicals were also tied directly or indirectly to secular publications, both by incorporating materials from them and by responding to charges levelled against Christian missions. However, they also show how the same technologies and publication regimes can be put to different ends. The mission presses made the Boxer War a different media event than the one emanating from secular journals and magazines. Suspense, anxiety, and seriality had their place, but they pointed to the otherworldly goals of Christian missions.

\footnotetext{
${ }^{135}$ James L. Hevia, English Lessons. The Pedagogy of Imperialism in Nineteenth-Century China (Durham, N.C.: Duke University Press, 2003), 236.

${ }^{136}$ See for example, "Why the Chinese are Aroused," Missionary Herald 96 (1900), 302; "Die evangelische Mission in China und ihre Ankläger," China-Bote 9 (1900), 76; Fr. Würz, "Was lehrt uns der vorjährige Preßfeldzug gegen die chinesische Mission?," Evangelisches MissionsMagazin 45 (1901), 133-142.
} 